\title{
Extraction and Characterization of Chitosan from Shrimp Shells
}

\author{
(Egypt : case study)
}

\author{
Yassmin G. Saleh*,Abir S. Nasr,Howida T. Zaki,Mansoura I. Mohamed,Nadia G. Kandile \\ Chemistry Department, Faculty of Women, Ain Shams University, Heliopolis11757 , Cairo, Egypt
}

\begin{abstract}
In the present study we reported the extraction of low cost chitosan's (CHS1, CHS2, CHS3 and CHS4) from shrimp shells by extraction of chitin, then alkaline deacetylation of chitin with strong alkaline solution at different period of time. The different prepared chitosan's (CHS1, CHS2, CHS3 and CHS4) were characterized by FTIR spectroscopy, thermal stability, morphology, crystallography, elemental analysis and degree of deacetylation. The data showed that the prepared chitosan CHS2 has the most thermal stability and the highest degree of deacetylation.
\end{abstract}

Keywords: Chitosan, Hydrogyl, Shrimp shells, Chitin, Morphology.

\section{Introduction}

A white hard polysaccharide chitin, which known as 2-acetamido-2-deoxy-D-gluco-pyranose units through $(1 \rightarrow 4)$ linkage is extracted from the crustaceans exoskeletons and also from crabs and shrimps (Minke and Blackwell, 1978; Austin et al., 1989). The alkaline deacetylation of chitin produces a very useful material chitosan, which known as a copolymer of $(1 \rightarrow 4)$ linked 2amino-2-deoxy-D-gluco-pyranose units, and also it is found naturally in some fungal cell walls. Since it is non-toxic and presents excellent biological properties such as biodegradation in the human body, immunological, antibacterial, and wound-healing activity (Synowiecki \& AlKhateeb, 2003; Jayakumar, Prabaharan, Reis, \& Mano, 2005), as shown in (Scheme 1), chitosan has been widely used in food and pharmaceutical processes and in medical and agricultural drugs (Kifune, 1992; Kawamura, Mitsuhashi,Tanibe, \& Yoshida, 1993; Ravi Kumar, 2000; Sashiwa \& Aiba, 2004) (Kandile N. G. , Nasr A. S.;2011). It can be found also in the skeleton of crab, shrimp and lobster, as well as in the exoskeleton of marine zooplankton spp., including coral and jellyfishes (Shahidi, F.; Abuzaytoun, R.,2005). Also, the chitin can be

*Corresponding author : Yassmin G saleh email: yassmin_saleh11@yahoo.com 
extracted from various sources to be converted to chitosan by different degree of dacetaylation during using different concentration of $\mathrm{NaOH}$ (Abdo E. S., Nagy Kh. S.A., Elsabee M. Z. ;2008)

\section{Scheme 1}

The aim of the present study is the preparation of low coast chitosan with different degree of deacetylation from wastes of Egyptian shrimp shells to use it as a key material for many applications.

\section{Materials and Methods}

\subsection{Materials}

Raw shrimps stated as large size were purchased from Egyptian (Market, Eloubor city, Egypt). Sodium hydroxide $(\mathrm{NaOH})$ (Aldrich, Egypt). Hydrochloric acid $(\mathrm{HCl})$ (Aldrich, Egypt), and acetic acid (Aldrich, Egypt). They were then diluted to the concentration required for the methodology with distilled water. All chemicals were used without further purification.

\subsection{Measurements}

The infrared spectra were measured on Perkin-Elmer-1430 infrared spectrophoto- meter using the potassium bromide Wafer technique. X-ray diffractograms of polymers were obtained with a 
Phillips X-ray radiation unit (Generator PW-1390) and Ni-filtered $\mathrm{Cu}$. Thermogravimetric analysis (TGA) was carried out in a nitrogen atmosphere using a Shimadzo TGA-50H. The morphology of the different hydrogels was investigated using JXA 850 prop micro analyzer scanning electron microscope (SEM). The solubility of the polymers was examined using $0.02 \mathrm{~g}$ of polymer in $5 \mathrm{ml}$ solvents at room temperature $25^{\circ} \mathrm{C}$.

\subsection{Methods (Extraction of chitosan)}

The extraction of chitosan can be carried out by different four methods under different conditions after removing the loose tissue from the shrimp shells then washed, dried and grind to obtain dry powder. The major procedure for obtaining chitosan is based on the alkaline deacetylation of chitin with strong alkaline solution at different period of time.

\subsubsection{Extraction :}

\section{Method 1}

\section{i. Deproteinization process}

The deproteinization was occurred by heating of $3 \mathrm{gm}$ of shrimp shells powder after adding $2 \mathrm{~N}$ $\mathrm{NaOH}$ with ratio of $12 \mathrm{ml}$ : $1 \mathrm{~g}(\mathrm{w} / \mathrm{v})$ at $70{ }^{\circ} \mathrm{C}$ for $4 \mathrm{~h}$. The product was neutralized by washing under running tap water. The solid was collected and washed with distilled water. The solid product was dried in vacuum and weighed with analytical balance.

\section{ii. Demineralization process}

The dry solid was treated with $10 \% \mathrm{HCl}(3.25 \mathrm{~N})$ with ratio of $14 \mathrm{ml}: 1 \mathrm{~g}(\mathrm{w} / \mathrm{v})$ at room temperature and kept for $4 \mathrm{~h}$.The solid product was collected and washed with distilled water. The solid was then dried.

\section{iii. Deacetaylation}

Then the demineralized product was treated with $35 \% \mathrm{NaOH}(8.75 \mathrm{~N})$ with ratio of 14 $\mathrm{ml}: \lg (\mathrm{w} / \mathrm{v})$ at room temperature for $75 \mathrm{~h}$. with stirring. Filter the deacetaylated solid then collected and washed with distilled water. The deacetaylated product was dried in a vacuum to give (1.51gm) and then labeled as CHS1.

\subsubsection{Extraction}

\section{Method 2}

\section{i. Demineralization process}


The demineralization was carried out by weight $3 \mathrm{gm}$ of shrimp shells powder by using $4 \% \mathrm{HCl}$ $(1.3 \mathrm{~N})$ with ratio of $14 \mathrm{ml}: 1 \mathrm{~g}(\mathrm{w} / \mathrm{v})$ at room temperature for $24 \mathrm{~h}$. The product was washed to neutrality under running tap water. The solid was collected and washed with distilled water, then dried in a vacuum.

\section{ii. Deproteinization process}

Deproteinization was carried out using $5 \% \mathrm{NaOH}(1.25 \mathrm{~N})$ with ratio of $12 \mathrm{ml}: 1 \mathrm{~g}(\mathrm{w} / \mathrm{v})$ at 90 ${ }^{\circ} \mathrm{C}$ for $24 \mathrm{~h}$. The deproteinized product was collected and washed with distilled water.

\section{iii. Deacetaylation}

The product was deacetylated with $70 \% \mathrm{NaOH}(17.5 \mathrm{~N})$ with ratio of $14 \mathrm{ml}: 1 \mathrm{~g}(\mathrm{w} / \mathrm{v})$ at room temperature for $75 \mathrm{~h}$. with stirring. The solid was collected and washed with distilled water. The deacetylated product was then dried in a vacuum, producing (2.04gm) and labeled as CHS2.

\subsubsection{Extraction :}

\section{Method 3}

\section{i. Deproteinization process}

The deproteinization process was carried out by weight $3 \mathrm{gm}$ of shrimp shells powder and using $5 \% \mathrm{NaOH}(1.25 \mathrm{~N})$ with a weight to volume ratio of $1 \mathrm{~g}: 8 \mathrm{ml}(\mathrm{w} / \mathrm{v})$. The solution with shrimp shells was refluxed at $70{ }^{\circ} \mathrm{C}$ for $3 \mathrm{~h}$. The product was collected and washed until clear solution. It was then dried in a vacuum. The product was decolorized with pure acetone for $24 \mathrm{~h}$. The product was collected and washed to neutrality, then dried.

\section{ii. Demineralization process}

The decolorized product was demineralized by using $1 \% \mathrm{HCl}(0.32 \mathrm{~N})$ with a weight to volume ratio of $1 \mathrm{~g}: 10 \mathrm{ml}$ for $24 \mathrm{~h}$. at room temperature. The product was collected and washed to give light brown powder.

\section{iii. Deacetaylation}

The N-deacetylation of the demineralized product was carried out by using $55 \% \mathrm{NaOH}(12.5 \mathrm{~N})$ with weight to volume ratio of $1 \mathrm{~g}: 5 \mathrm{ml}$ at $100{ }^{\circ} \mathrm{C}$ for $12 \mathrm{~h}$. The product was washed with distilled water and dried to producing (1.69gm) and then labeled as CHS3.

\subsubsection{Extraction :}

\section{Method 4}

\section{i. Demineralization process}


Weight $3 \mathrm{gm}$ of shrimp shells powder, then treated by $1 \mathrm{~N} \mathrm{NaOH}(4 \%)$ with weight to volume ratio of $1 \mathrm{~g}: 10 \mathrm{ml}$ for $24 \mathrm{~h}$. at room temperature. It was washed and dried in vacuum. The solid from the alkaline treatment were then demineralized by using $1 \mathrm{~N} \mathrm{HCl}(3 \%)$ with weight to volume ratio of $1 \mathrm{~g}: 10 \mathrm{ml}$ for $24 \mathrm{~h}$. at room temperature. It was washed and dried in vacuum.

\section{ii. Deproteinization process}

The demineralized product was deproteinized by using $1 \mathrm{M} \mathrm{NaOH}(4 \%)$ with weight to volume ratio of $1 \mathrm{~g}$ : $10 \mathrm{ml}$ for $24 \mathrm{~h}$. at room temperature. It was washed and dried in vacuum. The product from deproteinization was decolorized using pure acetone with for $24 \mathrm{~h}$. at room temperature. It was washed and dried in vacuum.

\section{iii. Deacetaylation}

From decolorization, the product was then deacetylated by using $50 \% \mathrm{NaOH}$ with weight to volume ratio of $1 \mathrm{~g}: 10 \mathrm{ml}$ for $24 \mathrm{~h}$. at room temperature. The product was washed and dried in vacuum to producing (1.14gm) and then labeled as CHS4.

\section{Result and Discussion}

The major procedure for extraction of chitosan from shrimp shells powder is based on the alkaline deacetylation of chitin with strong alkaline solution via deproteinization, demineralization and deacetaylation of shrimp shells powder at different conditions to give the following chitosan samples : CHS1, CHS2, CHS3 and CHS4 respectively.

\subsection{Characterization of the prepared chitosan}

The chitosan samples: CHS1, CHS2, CHS3 and CHS4 were characterized by (FT-IR) to identify the functional groups in chitosan. X-ray diffractometry (XRD) to analyze the crystallinity of the product, thermogravimetric analysis (TGA) to study the thermal stability, the elemental analysis to calculate the degree of deacetylation, Finally, Scanning electron microscope to demonstrate the morphology of the product.

\subsection{1 (FT-IR) Spectra}


The IR. spectral data for the produced chitosan [CHS1,CHS2, CHS3, and CHS4] revealed the following peaks: peak at $3440.9 \mathrm{~cm}^{-1}, 3396.1 \mathrm{~cm}^{-1}, 3438.7 \mathrm{~cm}^{-1}, 3441.5 \mathrm{~cm}^{-1}$ is assigned to $\mathrm{OH}$ and -NH stretching vibrations, while the peaks at $2960.8-2890.4 \mathrm{~cm}^{-1}, 2971.3 \mathrm{~cm}^{-1}, 2959.7-$ $2890.6 \mathrm{~cm}^{-1}, 2961.4-2890.5 \mathrm{~cm}^{-1}$ is assigned to the aliphatic C-H stretching vibration in the $-\mathrm{CH}$ and $-\mathrm{CH}_{2}$ groups. The amide frequencies consisting of the $-\mathrm{C}-\mathrm{O}$ bond stretch of the remaining acetamido groups and the $\mathrm{N}-\mathrm{H}$ bending vibrations of the $-\mathrm{NH}_{2}$ groups are observed at 1663.5 and $1559.9 \mathrm{~cm}^{-1}, 1754.1$ and $1664.7 \mathrm{~cm}^{-1}, 1659.5$ and $1561.7 \mathrm{~cm}^{-1}, 1656.3$ and $1562.5 \mathrm{~cm}^{-1}$ respectively. The peak at $1429.9 \mathrm{~cm}^{-1}, 1451.1 \mathrm{~cm}^{-1}, 1418.2 \mathrm{~cm}^{-1}, 1419.1 \mathrm{~cm}^{-1}$ is assigned to $\mathrm{NH}_{2}$ deformation. Further bending vibrations are observed at $1379.4 \mathrm{~cm}^{-1}, 1409.5 \mathrm{~cm}^{-1}, 1380.5$ $\mathrm{cm}^{-1}, 1381.8 \mathrm{~cm}^{-1}$ for the C-C-H symmetric bending vibration in the alcohol. Stretching vibrations are also observed at 1317.2 and $1156.9 \mathrm{~cm}^{-1}, 1154.5 \mathrm{~cm}^{-1}, 1316.0$ and $1156.8 \mathrm{~cm}^{-1}$, 1316.9and $1156.9 \mathrm{~cm}^{-1}$ for the C-N stretching vibration and at 1072.7 and $1032.3 \mathrm{~cm}^{-1}$ for the CO stretching vibration of the alcohol groups as shown in Fig.1

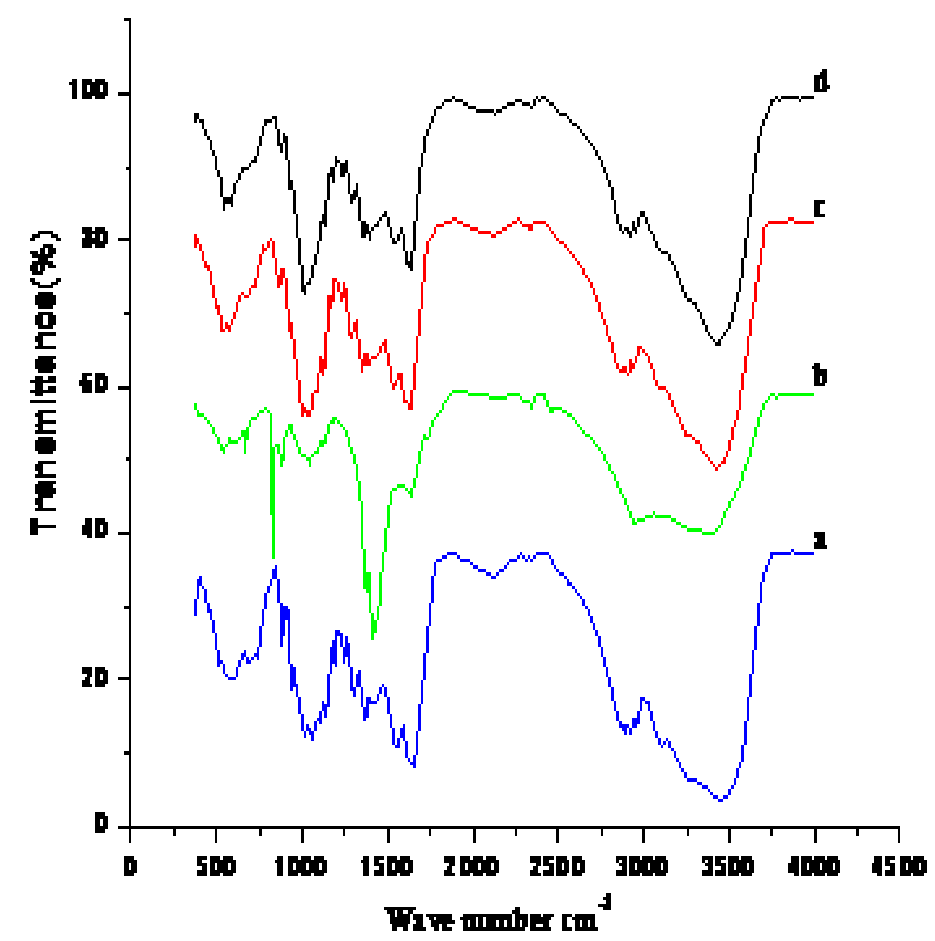

Fig.1. Infrared spectra of (a) CHS1, (b) CHS2, (c) CHS3 and (d) CHS4.

\subsubsection{X-ray Difratometry (XRD) Analysis}


The X-ray diffraction is used in the characterization of crystalline materials. By studying the Xray diffraction of the extracted chitosan from the four methods, it can be concluded that the order of crystallinity is of different chitosan samples: [CHS2 > CHS3 > CHS1> CHS4] so the highest crystallinity is shown by chitosan produced from method 2 [CHS2] as shown in Fig.2

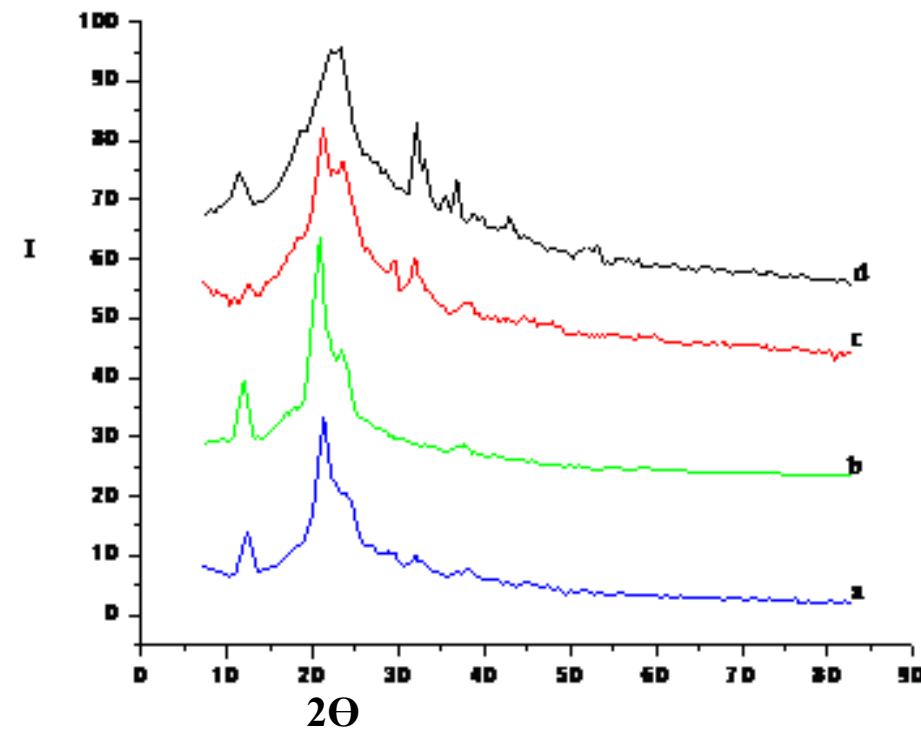

Fig.2. X-ray diffraction pattern for (a) CHS4,(b) CHS1,(c) CHS3and (d) CHS2.

\subsubsection{Thermal stability (Thermogravimetric Analysis) (TGA):}

The thermograph of the produced chitosans [CHS1, CHS2, CHS3, CHS4] were evaluated by using TGA in air at heating rate $10^{\circ} \mathrm{C} / \mathrm{min}$ and recorded in Fig (3) and Table (1): It show the following data: the weight loss of the extracted chitosan by the four methods at the beginning may be due to the ease of degradation of the amide groups; however the weight loss in the high temperature range is attributed to the degradation of the main chain.

Table (1): Thermal properties of the extracted chitosan by the four methods 


\begin{tabular}{|c|c|c|c|c|c|c|}
\hline $\begin{array}{c}\text { method } \\
\text { code }\end{array}$ & Temp. & $\begin{array}{c}\text { Wt. } \\
\text { Loss } \%\end{array}$ & Temp. & $\begin{array}{c}\text { Wt. } \\
\text { Loss } \%\end{array}$ & Temp. & $\begin{array}{c}\text { Wt. } \\
\text { Loss\% }\end{array}$ \\
\hline Ex1_CHS & 230.0 & 13.63 & 690.0 & 25.17 & - & - \\
\hline Ex2_CHS & 250.0 & 10.82 & 283.33 & 5.105 & 550.0 & 27.84 \\
\hline Ex3_CHS & 225.0 & 10.89 & 704.16 & 53.33 & - & - \\
\hline Ex4_CHS & 195.83 & 9.14 & 391.66 & 31.60 & 629.16 & 32.60 \\
\hline
\end{tabular}

From the Table (1), it can

be concluded that: the polymer prepared by method (2) (CHS2), show high thermal stability than the other prepared samples.

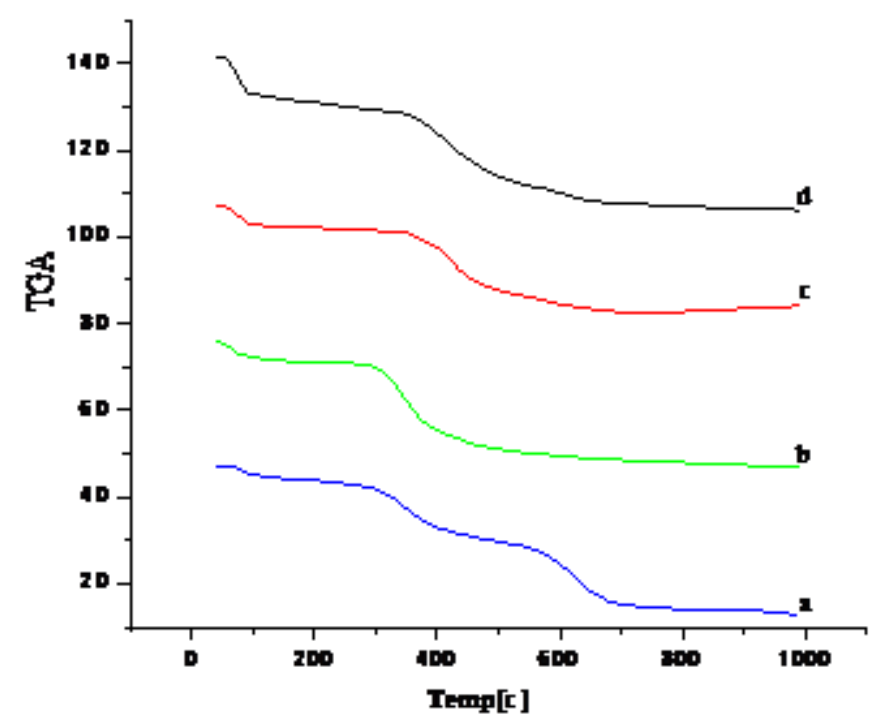

Fig. (3). TGA for (a) CHS1, (b) CHS2, (c) CHS3 and (d) CHS4.

\subsubsection{Degree of deacetylation for Chitosan}

By using the elemental analysis the percentage of free amino groups on the chitosan can be determined by using the following equation (Kasaai, Arul \&Charlet, 2000): 
Where 5.145 is related to completely $\mathrm{N}$-deacetylated chitosan $\left(\mathrm{C}_{6} \mathrm{H}_{11} \mathrm{O}_{4} \mathrm{~N}\right.$ repeat unit) and 6.186 is the fully $\mathrm{N}$-acetylated polymer $\left(\mathrm{C}_{6} \mathrm{H}_{11} \mathrm{O}_{4} \mathrm{~N}\right.$ repeat unit). The value of degree of deacetylation of chitosan samples was calculated and reported in Table (2). The data indicated that the highest degree of deacetylation (DD) shown by the CHS2, CHS3 .It can be conclude that the degree of deacetylation of chitosan increased by increasing the concentration of the $\mathrm{NaOH}$ used in. The elemental analysis and the degree of deacetylation shown in Table (2).

Table (2): The elemental analysis, and the degree of deacetylation of chitosan

\begin{tabular}{|c|c|c|c|c|}
\hline $\begin{array}{c}\text { method } \\
\text { code }\end{array}$ & $\% \mathrm{C}$ & $\% \mathrm{H}$ & $\% \mathrm{~N}$ & $\mathrm{DD} \%$ \\
\hline CHS1 & 40.66 & 5.75 & 6.65 & 6.917 \\
\hline CHS2 & 28.90 & 3.70 & 5.51 & 90.4 \\
\hline CHS3 & 31.80 & 2.80 & 6.01 & 85.95 \\
\hline CHS4 & 27.6 & 3.82 & 4.30 & 21.0 \\
\hline
\end{tabular}

\subsubsection{Morphology}

The SEM photographs shows the morphologies of the four extracted chitosan as shown in Figs. (4-7) which show the morphologies of the extracted chitosan by methods (1,2,3 and 4) at $(200,50,30 \mu \mathrm{m})$ respectively. The Figs. show that the different in the shape of each Fig. according to the different method of preparation of each method of chitosan. 


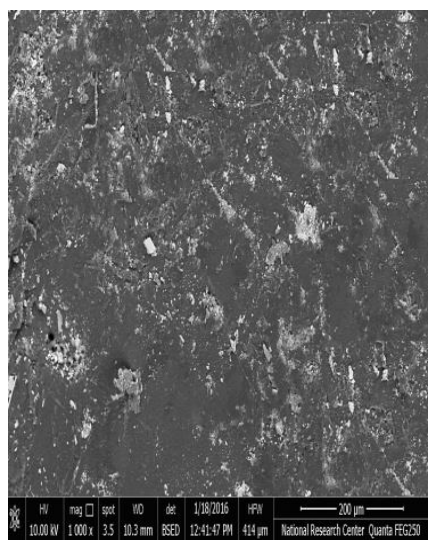

(a)

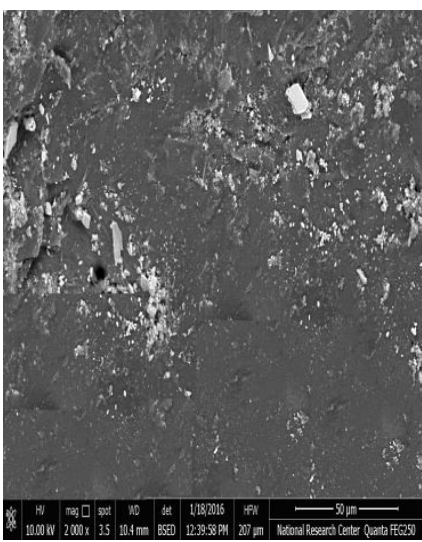

(b)

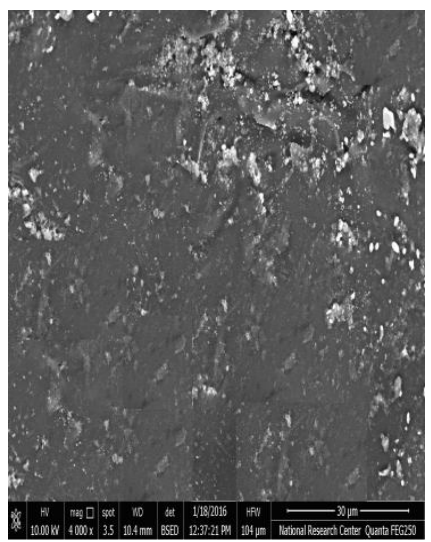

(c)

Fig.4. SEM of CHS1 at (a) $200 \mu \mathrm{m}$. (b) $50 \mu \mathrm{m}$. (c) $30 \mu \mathrm{m}$.

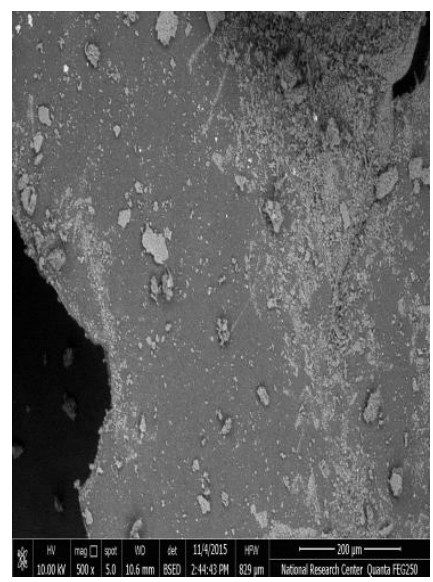

(a)

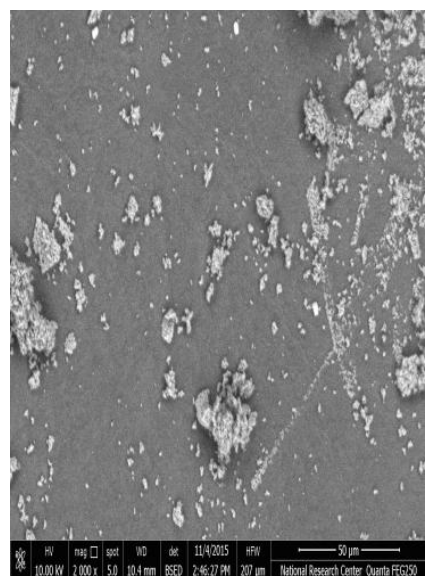

(b)

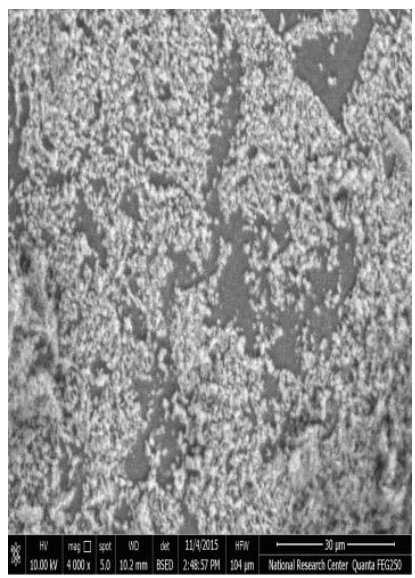

(c)

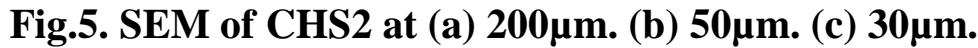



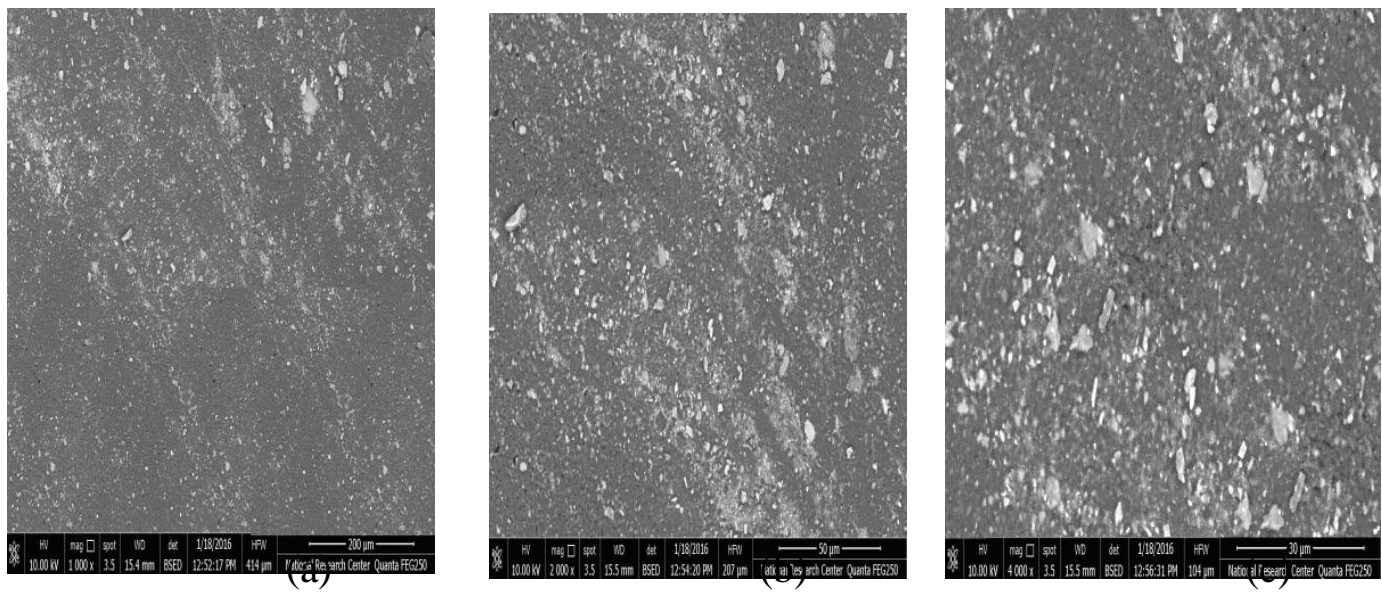

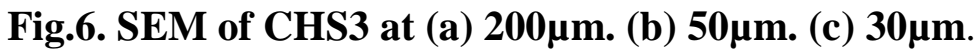

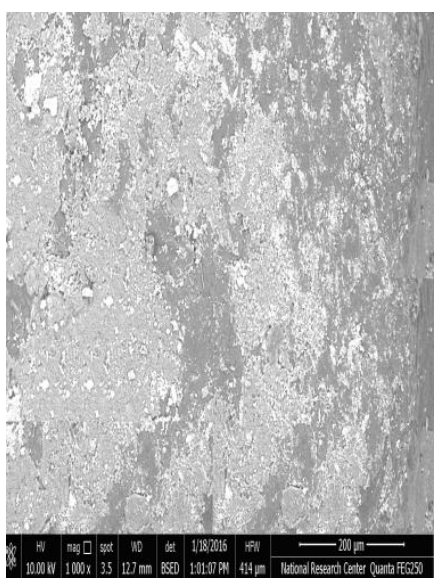

(a)

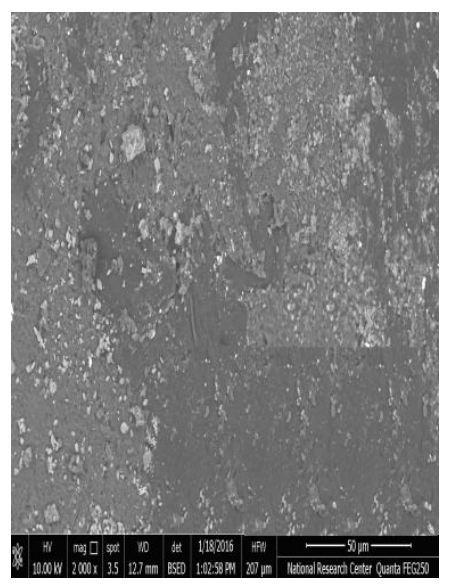

(b)

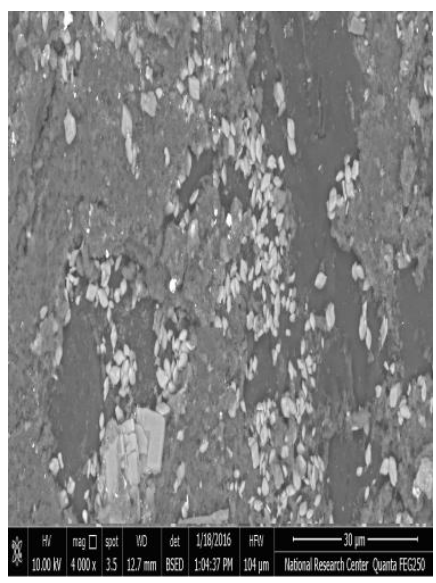

(c)

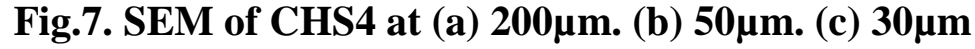

\section{Conclusions}

Chitosan's of different degree of deacetylation can be obtained from deacetylation of chitin in strong sodium hydroxide solution at different period of time after extraction from shrimp shells . Chitosan (CHS2) possesses the highest thermal stability, crystallinity and degree of deacetylation which may be attributed to the increase of the sodium hydroxide concentration, and its morphology shows crystals on its smooth surface. 


\section{References}

Abdou, E.S., Nagy, Kh.S.A., Elsabee, M.Z., Extraction and characterization of chitin and chitosan from local sources. Bioresource Technology 99 , 1359-1367 (2008).

Jayakumar, R., Prabaharan, M., Reis, R. L., \& Mano, J. F., Graft copolymerized chitosan present status and applications. Carbohydrate Polymers, 62, 142-158 (2005).

Kasaai, M. R., Arul, J., \& Charlet, G., Intrinsic viscosity-molecular weight relationship for chitosan. Journal of Polymer Science. Part B: Polymer Physics, 38(19), 2591-2598 (2000).

Kawamura, Y., Mitsuhashi, M., Tanibe, H., \& Yoshida, H., Adsorption of metal ions on polyaminated highly porous chitosan chelating resin. Journal of Industrial and Engineering Chemistry Research, 32, 386-391 (1993).

Kifune, K., In Brine, C. J., Sanford, P. A., \& Zikakis, J. P., (Eds.), Advances in chitin and chitosan (p. 9). Essex, England: Elsevier. (1992).

Minke, R., Blackwell, J., The structure of a-chitin. Journal of Molecular Biology 120, 167 (1978).

Kandile, N.G., Nasr, A.S., Hydrogels based on three component system with potential for leaching metals. Journal of Carbohydrate Polymers 85, 120-128 (2011).

Ravi Kumar, M. N. V., A review of chitin and chitosan applications. Reactive and Functional Polymers, 46, 1-27 (2000).

Sashiwa, H., \& Aiba, S., Chemically modified chitin and chitosan as biomaterials. Progress in Polymer Science, 29, 887-908 (2004).

Shahidi, F., Abuzaytoun, R., Adv. Food Nutr. Res., 49, 93- 135 (2005).

Synowiecki, J., \& Al-Khateeb, N. A., Production, properties, and some new applications of chitin and its derivatives. Critical Reviews in Food Science and Nutrition, 43, 145-171 (2003). 


\section{الملخص باللغة العربية}

\section{إستخلاص وتوصيف الكيتوزان من قشور الجمبري}

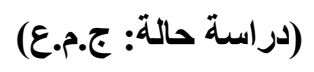

\section{ياسمين جمال، عبير صلاح ناصر، هويدا طلعت زكي، منصورة إسماعيل محمد، نادية غريب قنديل}

$$
\begin{aligned}
& \text { • يتضمن هذا البحث كيفية إستخر اج الكيتوز ان من قشور الجمبري وذلك عن طريق استخر اج الكيتين ثم تحويله الى } \\
& \text { الكيتوز ان في وسط قاعدى قوى لنزع مجمو عات الأسيتيل مع إختلاف الوقت اللازم للتفاعل. }
\end{aligned}
$$

\section{• تم تحضير الكيتوز ان بأربع طرق مختلفه لتحضير CHS1, CHS2, CHS3 and CHS4.}

• وقد تم توصيف جميع التر اكيب الكيميائيه بطرق متعددة مثل:تحليل العناصر عن طريق الوحدات المتكررة لكل بوليمر

وكذللك الدر اسه الطيفيه لها باستخدام الاشعة تحت الحمر اء، و الثبات الحر اري بإستخدام التحليل الحرارى، ودر اسة

الثكل البللوري بإستخدام أشعة إكس، كما تم در اسة المورفولوجى للبوليمر ات بإستخدام الماسح الإكترونى بـى بـ

$$
\text { الميكروسكوبى. }
$$

• أظهرت النتائج أن الكيتوزان الذي تم تحضيره بالطريقة الثانية هو أكثر ثباتا حر اريا وأعلي درجه في نزع مجمو عة 